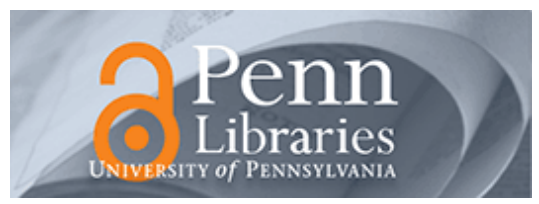

\author{
University of Pennsylvania \\ ScholarlyCommons
}

Information \& Communication Technology -

Africa

Annenberg School for Communication

2009

\title{
An Exploratory Study of Strategies to Improve Africa's Least Developed Economies' Telecommunications Infrastructure: The Stakeholders Speak
}

V.W. Mbarika

T Byrd

Follow this and additional works at: https://repository.upenn.edu/ictafrica

Mbarika, V.W. and Byrd, T, "An Exploratory Study of Strategies to Improve Africa's Least Developed Economies' Telecommunications Infrastructure: The Stakeholders Speak" (2009). Information \& Communication Technology - Africa. 11.

https://repository.upenn.edu/ictafrica/11

This paper is posted at ScholarlyCommons. https://repository.upenn.edu/ictafrica/11

For more information, please contact repository@pobox.upenn.edu. 
An Exploratory Study of Strategies to Improve Africa's Least Developed

Economies' Telecommunications Infrastructure: The Stakeholders Speak 


\title{
AN EXPLORATORY STUDY OF STRATEGIES TO IMPROVE AFRICA'S LEAST DEVELOPED ECONOMIES' TELECOMMUNICATIONS INFRASTRUCTURE: THE STAKEHOLDERS SPEAK ${ }^{1}$
}

\begin{abstract}
To enjoy modern information technology applications for development such as e-medicine, tele-edcuation, e-government and e-commerce, the engineering management and information systems literature have vastly argued that there exist technological and non-technological precursors to successful diffusion of such applications. Factors such as training local expertise and open competition that could be taken for granted in developed nations cannot just be ignored in the case of developing economies. The main measure of a nation's telecommunications infrastructure is teledensity - the number of main telecommunications landlines per 100 people. Africa's Least Developed Economies (LDEs), home to 33 of the 48 LDEs of the world, continue to suffer from poor telecommunications infrastructure. For most countries within this region, less than one telephone line is shared among 100 inhabitants, a serious hindrance in building other basic infrastructure such as the Internet and related technologies. For example, Congo and Eritrea still have less than 0.5 line per 100 people. This study examines the perceptions of Africa's technology stakeholders to solve the poor telecommunications infrastructure problems that hinder diffusion of relevant applications within the region. Both qualitative and quantitative data was collected and reported in this study. Findings reveal six pertinent factors (strategies) that would impact teledensity growth in Africa's LDEs: (1) Promote domestic and foreign investment in ICTs; (2) Develop wireless and satellite infrastructure as a compliment (and not a replacement) to land-lines; (3) Strive to be self sufficient; (4) Enact governmental regulatory policies; (5) Build local capacity; and (6) Privatize the telecommunications sector.
\end{abstract}

Keywords: Telecommunications, teledensity, information technology infrastructure, economically developing nations, Sub-Saharan Africa.

\footnotetext{
${ }^{1}$ Acknowledgements: This research was based upon work supported by the National Science Foundation under Grant No. IIS\# 0644305. Any opinions, findings, and conclusions or recommendations expressed in this material are those of the author(s) and do not necessarily reflect the views of the National Science Foundation.
} 


\section{INTRODUCTION AND RESEARCH QUESTIONS}

In a recent engineering management publication, Jelinek and Markham (2007) persuasively show how policies (a non-technological factor) impact transfer of technology and innovations as well as eventual use of these technologies. Ignoring such factors, as well as other technological and non-technological factors have accounted for the acutely poor telecommunications infrastructure of developing nations such as those in Sub-Saharan Africa (SSA) (Meso et al., 2007; M'Sene, 2007; Kifle et al., 2007).

The lack of basic telecommunications infrastructure is a severe hindrance to the growth of the information and communications technologies (ICT) in any country (Kaba et al., 2008; Kifle et al., 2008; M'Sene, 2007; Meso et al, 2005). Previous research has associated the level of a country's basic telecommunications infrastructure with its teledensity (Meso et al., 2007b; Jhunjhunwala, 2003; Mbarika et al., 2005), defined as the number of land telephone lines per 100 people. While telephone lines have been traditionally used for voice communications, in virtually every country of the world, when the market sufficiently matured for such a need, they have eventually formed the national backbone of data communications. Thus, teledensity remains an important indicator of national telecommunications infrastructure. Although the adoption rate of cellular is high in some countries like Nigeria, the diffusion of landlines is still needed to provide the needed backbone connection as well as to provide data transmission services that require high levels of data security. Wireless telephony still suffers from susceptibility of signal interception. Hence, the fiber optic undersea connection which is in progress throughout Africa will hopefully provide the much needed reliable land line connection working hand-in-hand with existing wireless technologies. Although wireless telecommunications media such as cellular telephony and VSAT are in the early adoption stage in Africa's LDEs, research-to-date still views land-line teledensity as a consistent pre-requisite to ICT development (Meso et al., 2007b).

Africa's Least Developed Economies (LDEs) significantly lag behind other regions of the world in terms of teledensity, and with this disadvantage, the prospects of catching up with more developed countries in terms of ICT adoption look grim (Kifle et al., 2007). In all of Africa, there is less than one telephone line per 100 persons for most LDEs within the region (Meso et al., 2007; ITU 2007). These figures are 
substantially lower than even the 2006 figures of 9 per 100 in Asia, 10 in Latin America and the Caribbean, 37 in Europe, and 66 in the United States (ITU, 2007). It is only in November 2000, for example, that the East African country, Eritrea, obtained a local Internet connection and finally brought all 54 of Africa's countries and territories online.

Mbarika et al. (2003) persuasively put forward four main obstacles to the growth of teledensity in Africa's LDEs. These obstacles, which will be discussed in details later, include organizational obstacles such as existing governmental monopoly of the telecommunications sector that hinders competition and that results in poor services; financial obstacles such as the unavailability of appropriate funding needed to develop the region's telecommunications infrastructure; technological issues such as lack of the necessary technical expertise to build, operate and maintain telecommunications related equipment; and geographical obstacles such as the virtual exclusion of rural regions in Africa, from access to basic telecommunications infrastructure. While Mbarika et al. (2003) present these pertinent obstacles, they fall short of suggesting specific strategies to address the dilemma; hence the essence of our current study.

In considering these four obstacles, the first research question is “What strategies can Africa's LDEs adopt to overcome obstacles to telecommunications diffusion?" To address this question, we first search the research literature to determine strategies that had been suggested in overcoming the obstacles. We then asked African governmental and non-governmental technology stakeholders to rank these strategies to ascertain the best one for overcoming its respective obstacle.

The technology stakeholders in Africa are made up of governmental and non-governmental stakeholders. The governmental stakeholders include government and para-statals, and telecommunication operators (government controlled). The non-governmental stakeholders include telecommunication operators (non-government controlled), academia, research centers and IT experts, and international/regional organizations. Both the governmental and non-governmental stakeholders have typically played a major role in the implementation of IT at national levels in most developing economies (Montealegre, 1999; Jhunjhunwala, 2003). However, they have also differed in their approaches to address the telecommunications infrastructure challenges of their countries (Kifle et al., 2008; Meso et al., 2007b). 
The differences in stakeholders' perceptions propel us to our second research question: Are there any differences in the perception of strategies between governmental and non-governmental stakeholders? We therefore want to know if there are differences, and if so, what the differences are. If differences exist, it is important to know what they are so that they can be addressed and resolved. Similarly, if there is agreement, then such strategies can be consolidated so as to minimize fragmentation in approaches to address the region's telecommunications dilemma.

The engineering management, information systems and developmental literature have investigated factors that affect development of telecommunications infrastructure worldwide and specific applications of the same in developing economies (Meso et al., 2007a,b; Loch et al., 2003; M'Sene, 2007; Travica 2002; Wolcott, et al., 2001). Major findings show that telecommunications applications are being acquired and implemented in SSA countries at an exponential rate (Kifle et al., 2007; Mbarika 2004a,b; Mbarika et al., 2002a, Mbarika \& Mbarika, 2006, Okoli et al., 2005; Straub et al., 200; Loch et al., 2003; Diop, 1997). Unfortunately, most of these previous studies have jumped to look at complex applications for developing nations without stepping to understand strategies address major infrastructure bottlenecks needed to implement sound applications. There is a strong need to understand the contextual settings of the developing economies being studied in order to effectively apply such technologies(Musa et al., 2005; Lock et al., 2003).

This exploratory study examines and suggests a comprehensive set of strategies to solve Africa's LDEs growing problems of low telecommunications access (measured in terms of teledensity). We therefore provide an early entry point to study this under-researched and complex region of the world.

\section{RESEARCH MOTIVATION}

As discussed in the previous section, governmental and non-governmental stakeholders have traditionally suggested different strategies to address the many telecommunications-related problems of their countries. For instance, some stakeholders believe the telecommunications operator should be a governmentcontrolled monopoly for reasons of national security. Other stakeholders believe the telecommunications operator should be liberalized to allow for free entry, thereby promoting competition, which will benefit the 
national economy and improve on the status of telecommunications activity (Mbarika et al., 2002a). Some stakeholders--international development organizations--charged with assisting LDEs, regard highly developed telecommunications infrastructure as an urban luxury (Hudson, 2002). On the other hand, academicians have argued on the importance of having universal services in order to close the gap between telecommunications infrastructure of urban and rural areas.

It is therefore clear that technology stakeholders have traditionally gone in different directions while deciding on the best strategies to overcome problems with technological infrastructure for telecommunications in their countries. If we understand how the different stakeholder groups are similar or different in their views of strategies, it is easier to negotiate, compromise, and ultimately get broader based support for strategies. Further, and especially in the case of Africa's LDEs, it is important that these nations not just rush to copy what the more developed West has used as strategies without careful insight on their specific socio-cultural and political context. There may be some underlying assumptions in the developed West that may not apply to Africa's LDEs and so context may need to be taken into consideration to define, motivate and implement such strategies. Our study on teledensity as the basic measure of a nation's telecommunications infrastructure could provide a starting point to stakeholders in Africa's LDEs to catapult strategies for growth of this very important infrastructure needed for relevant applications.

Teledensity remains a key factor of interest in the developmental potential of Africa's LDEs. First, the telephone infrastructure is the core backbone upon which the region can implement and develop information-age services such as e-commerce, m-commerce, e-medicine, and e-government. Second, it enables and empowers vast numbers of users to access telephone and Internet-based communication services such as email, web browsing, instant messaging, and text messaging among others. Adequate communications infrastructure enables citizens to access the global resource pools of knowledge, information, finances and markets that empower them to effectively engage in capacity building, income generation and skills-acquisition activities beneficial to the local communities in which they belong. Third, enhanced teledensity provides the means by which many more citizens can become actively involved in the governance process and contribute effectively to governance issues of the day. As such, enhanced teledensity 
has the potential for leveraging the quality of governance (World Bank, UNDP, etc,). Fourth, growing teledensity holds the promise of enabling sub-Saharan countries to effectively and significantly participate in the global financial, securities, and commodities markets. Presently, participation in these highly digitized markets requires extensive levels of high-bandwidth teledensity. Appropriate bandwith levels still remain a major dream for most LDEs.

Currently there are 48 LDEs as defined by the United Nations, 33 of which are in Africa. The poor state of telecommunications infrastructure in these LDEs is staggering and has greatly hindered diffusion of related applications that could benefit these nations (M'Sene, 2007; Jhunjhunwala, 2003). For example, while there are only about two main telephone lines per 100 persons in Africa, such low levels of teledensity are even worse for Africa's LDEs, with less than one telephone line per 100 persons (ITU, 2007).

\section{THEORETICAL BACKGROUND}

\section{Obstacles to Telecommunications Diffusion in Africa's LDEs}

Given the tremendous opportunities for LDEs to leverage the potential in telecommunications and related technologies, the question is why are they not doing so? In a recent comprehensive study of telecommunications issues in Africa's LDEs, Mbarika et al. (2003) persuasively put forward several obstacles to the growth of teledensity in the region. These obstacles and supporting literature follow.

\section{Organizational Obstacles}

The regulatory frameworks of some Africa's LDEs such as Ethiopia indicate that the governments still have monopoly power over these countries' telecommunications infrastructure. Access to communications channels is largely controlled by state monopolies. In a World Telecommunications Development Report, the ITU points out that a major obstacle to the telephone line penetration in LDEs was that telephone services are provided by monopolized, government-run organizations, limiting the incentives for better performance (Meso et al., 2007).

The government monopolies of many LDEs lack basic knowledge of key global trends in information technology (Meso et al., 2007b). Although the governments of these countries do not directly 
control the penetration of Internet hosts in these countries, they do have control over the diffusion telephone lines needed for Internet access. Pressure from international financial institutions such as the World Bank and the International Monetary Fund following the sharp decrease in fiscal revenue forced the public telecommunications monopolies during the 1980 s and the 1990 s to carry out major reforms. Thus the ICT sector was deregulated as a whole, with the telecommunication industry privatized. Even as some progress is made, the continuously poor quality of service, the lack of even accessibility and the ridiculously long wait to subscribe and operate a landline are among the factors that constrain the development of telecommunications in Africa today, and impact teledensity growth.

\section{Financial Obstacles}

Africa's LDEs are faced with very weak economic structures. The financial obstacles include low Gross Domestic Product (GDP), low GDP per capita, and insufficient financial autonomy of the operating entities. These financial constraints pose major problems for LDEs that generally have a very low average per capita income of only about US $\$ 283$ per year. This amount is just 7 percent of the global average income of US $\$ 3,980$ per year. As evident in other sectors, there is a perpetual scarcity of foreign exchange for private sector investments in the telecommunications sector. This makes the cost of importing computing and telecommunications equipment almost unaffordable. Furthermore, the poor state of the LDEs' banking systems makes it difficult for Africa's LDEs to carry out telecommunications transactions that may necessitate the use of credit cards and other financial related transactions that require the use of a banking institution (Okoli, 2003).

It is worth noting that many countries in sub-Saharan Africa broke away from state control of the economy and liberalized their financial sectors in the late 1980 s or 1990 s to foster greater managerial efficiency. Despite the new developments and the overall improvement of the economic performance, comparable efforts undertaken in many African countries to restructure the banking system were met with failure. A large proportion of these countries populations are still unable to access banking services because conventional banking is expensive relatively to their income. The modern, efficiently-organized banking sector remains confined to the urban centers, while the rural segment of the population and their financial 
resources and needs are kept out of the financial intermediating mechanisms. These banks require documentation to open an account, such as proof of income and address, which many lack. Bank fees in Africa are also some of the highest in the world. Without access to a bank account, many persons in Africa are stuck in the informal, cash-only economy.

\section{Technological Obstacles}

Technological issues are major concerns in providing adequate growth of teledensity in Africa's LDEs; the city of New York or the Tokyo conurbation has more telephone lines than the whole continent of Africa (Mbarika, 2001). Because the telephone systems in Africa's LDEs were most likely placed to serve the needs of government, they tended to be confined to major cities. This has left most of the rural population of Africa's LDEs (which is at least $70 \%$ of the total population) without any form of telephone access.

As reported in Meso et al. (2007) and in Wilson and Wong (2003), LDE's typically use outdated equipment needed to provide the connection lines. The equipment is also inadequately maintained, resulting in poor quality of service and loss of revenues. In some LDEs such as Cameroon, for example, malfunctioning telephone equipment could be out of service for months before a maintenance team arrives to attempt any repairs. Even after problems are identified, the maintenance process is generally slow, partly because the technicians demand bribes.

\section{Geographical Obstacles}

Various geographical barriers to remote areas as well as lower monetary returns from those areas reduce incentives to extend telecommunications-related infrastructure to those areas. Therefore, most private investors have little or no incentive to establish technology links in rural areas where most of the people live. Such geographical barriers to remote areas are a major problem to most telecommunications-related issues for developing economies in general.

Government monopolies of LDEs lack a universal access policy, which explains why many rural areas do not have any form of telecommunications access (Meso et al., 2007). In this paper, we explore the perceptions of technology stakeholders of Africa's LDEs. Using a list of experts from an ITU / UN database, a sample of the stakeholders was asked to rate some telecommunications-related strategies in terms of 
perceived criticality. We then analyze the data to determine if significant differences in perceptions existed compared to actual trends in the growth of teledensity in recent years.

\section{METHODOLOGY}

\section{Survey Instrument and Administration}

A survey instrument was developed that listed strategies found in the literature. The items for the strategies were derived from a comprehensive review of academic literature and publications of development organizations. The literature review covered a 15-year range and sources searched include ABI INFORM, the Academic Search Elite (EBSCO Host) databases, and a "Bibliography of Telecommunications and Socio-Economic Development".. Additionally, emails were sent to two major list-serves-ISWORLD and AFRIK-IT. These list-serves involved members of IT community worldwide involved in research and industry in the area of IT in Africa. The email requested for members of the list-serves to provide the authors with references in the area of strategies to overcome obstacles to telecommunications infrastructure in Africa's LDEs or contacts of individuals that could help.

The academic literature was peer-reviewed journals and major conference proceedings that focused on IT for socio-economic development. Other major academic publications used for this work are books written and published in the subject area of telecommunications for socio-economic development. The leading journals in IT and Telecommunications for socio-economic development such as JMIS, ISR, Telecommunications policy, Journal of Global Information Management, IEEE Technology and Society Journal, Telecommunications Review, Telecommunications Journal, Journal of Economic Development, Pacific Telecommunications Review. Some leading conference proceedings used in this study include World Telecommunications Forum, Africa Telecom conference, Africa Regional Symposiums on Telematics, ITU World Telecommunications Development Conference. Publications of development organizations used in this study include Siemens Review, ITU World Telecommunications Development Reports (multiple years), World Bank Development Reports (multiple years), Panos Institute of London publications on “The Internet and Poverty." 
The items for the survey questionnaire were developed using a scale from 1 (strongly disagree) to 7 (strongly agree) to the agreement of the set of strategies for each obstacle. The respondents were provided the opportunity to also provide comments on how they felt about the suggested strategies. Some of the comments are included in the discussion section of this paper.

A pilot test of the questionnaire was conducted by randomly selecting participants from the list provided by the ITU. However, participants were unaware of their role in the pilot test. This pilot test involved 15 participants. We asked the stakeholders to give comments on the understandability of the items for the different strategies. Questions that were unclear were corrected to make them more meaningful while certain redundant questions were thrown out of the survey. This resulted in a revised survey instrument that was used to collect data for the full survey.

The full survey was administered to the aforementioned technology stakeholders who were given the option of using traditional paper-based or web-based technologies. These respondents (stakeholders) were selected from the same ITU list as those who participated in the pilot survey. The issue of any potential response bias, based on our use of web-based data collection, was very minimal since these stakeholders have access to and use the Internet, fax, and most telecommunications-based technologies. An important aspect of data collection is that all techniques have differing advantages and disadvantages. Researchers have argued for the use of multi-method approaches for data collection (Brancheau and Borton, 1999; Yin, 2002). Also many researchers have argued for the importance of web-based survey in improving response time while still sustaining the reliability and validity of data (e.g., Alreck and Settle 1996; Kueng and Wettstein, 1999). Respondents using the paper questionnaires were provided a fax number to use in order to return the survey. Respondents could also simply mail back the survey.

We offered the respondents a little incentive if they completed the survey. To this, we gave them an option to request for a free summary report of our research findings. Most of the respondents did request for the report. A summary of items (questions) used in the survey are presented in Tables 1, 2, 3 and 4.

\section{Table 1: Descriptions of factors under Organizational/Policy-Oriented Strategy}


1. Turn the telecommunications operator into an independent company with complete autonomy.

Mbarika et al (2003);

Ras-Work (1995);

2. Sell shares of the telecommunications operator to the public.

McCoy and Mbarika

(2005);

3. Encourage competition among the telecommunications operators.

Jensen (1999)

4. Establish an impartial, non-governmental regulatory body to control the telecommunications industry.

Mbarika et al., 2002;

Ras-Work (1995);

Sekizawa (1995); UN-

ECA (1999)

5. Establish an impartial, non-governmental regulatory body to set and uphold standards within the telecommunications industry.

Sekizawa (1995)

6. Establish an impartial, governmental regulatory body to control the telecommunications industry.

Mbarika et al (2003)

7. Establish an impartial, governmental regulatory body to set and uphold standards within the telecommunications industry.

Table 2: Descriptions of factors under Technological-Oriented Strategy

Description $\quad$ Literature Sources

8. Africa's LDEs should review the possibilities for local or regional Mbarika et al (2003) manufacture of telecommunications equipment.

9. Operators and manufacturers should enhance the training opportunities they offer to telecommunications staff of Africa's LDEs.

10. Africa's LDEs should be trained to carry out monthly routine maintenance of already existing equipment.

Okoli (2003);

Motealegre (2001);

McCoy and Mbarika

(2005)

11. Africa's LDEs, with assistance of funding organizations, should set up long-term contracts to buy new knowledge from developed countries (i.e. advocate for joint ventures).

12. Development organizations should conduct seminars to improve the qualifications of experts of Africa's LDEs.

13. Africa's LDEs should solicit help from developed countries to build and install their telecommunications equipment.

14. When purchasing equipment from foreign countries, Africa's LDEs should ensure that the contract includes commitments on the supply of spare parts and post-installation review.

Mbarika (2001)

UN-ECA (1999)

Mbarika et al., 2002;

McCoy and Mbarika (2005)

15. Africa's LDEs should hire foreign experts to perform thorough routine Mbarika (2001) maintenance of already existing equipment.

Table 3: Descriptions of factors under Financial-Oriented Strategy 
16. Devote 1 to 2 percent of GNP to telecommunications investment.

17. Africa's LDEs governments should subsidize the local telecommunications industry in order to expand their turnover and employment.

18. To save cost of equipment purchase, Africa' LDEs should consider pooling their purchases of commonly used equipment including terminals and components.

19. Encourage growth in the service sector (tourism, transportation, etc), which will be a major source of income that can in turn increase the provision for more phones.

20. Countries and international agencies with development assistance programs should give higher priority to growth of teledensity in Africa's LDEs.

21. Funding institutions must ease conditions to grant loans for the purpose of establishing basic telecommunications infrastructure in Africa's LDEs.

22. Encourage private investments through the reorganization of the sector and by using policy to direct investment into the sector.

23. Encourage the participation of foreign private investors in funding directed towards growth of teledensity.
Panos (1998)

Mbarika (2001)

Mbarika et al. (2003)

Jensen (1999)

Mbarika et al. (2003)

Mbarika (2001)

Maddy (2000);

Panos (1998)

Table 4: Descriptions of factors under Geographical-Oriented Strategy

Description

24. Mobile satellite services and fixed cellular networks should be installed.

25. Use satellites to provide telecommunications in Africa's LDEs due to the ubiquitous coverage offered by satellite technology.

26. Use semi-fixed analog mobile phone cells placed in communities without telecommunications along with cheap handsets and a VSAT link to regional hubs.

27. Telecommunications service carriers in rural areas should be provided easy loan requirements, lower taxes, and ease to register such businesses.

28. Mandate that new service providers serve both urban and rural areas, using resources of urban areas to subsidize rural areas.

29. Encourage private investors to establish pay phone services such as public Jensen (1999) telephone booths.
Literature Sources

Harrington (1995);

Cutler (1994)

ITU (1998);

ITU (1998)

Meso et al. (2005) 
30. Encourage private investors to establish telecentres or shared community Jensen (1999); ITU access in order to promote use of telephone services and other forms of (1998) shared access, which could in turn promote use of advanced services such as the Internet.

\section{RESULTS}

Of the two hundred and twelve questionnaires sent to individuals, one hundred and five responses were returned, which corresponds to a response rate of $49.5 \%$. We were limited to this sample size because our target sample included participants (stakeholders) that had a significant level of control over their specific institutions (for the non-governmental stakeholders), and ministries, governmental sub-departments or organizations (for governmental stakeholders). It is our understanding that this is a high rate, especially when compared to results from other surveys and studies. Of the 105 technology stakeholders, 58 were governmental stakeholders and 47 were non-governmental stakeholders. Below is a description of the various respondents:

Table 5: Survey Participants

\begin{tabular}{lll}
\hline \multicolumn{3}{c}{ Total Number of Respondents $=106$} \\
\hline Stakeholder Affiliation & $\begin{array}{l}\text { Gov't S. H. } \\
(\mathrm{n}=59)\end{array}$ & $\begin{array}{l}\text { Non-Gov't S. H. } \\
(\mathrm{n}=47)\end{array}$ \\
\hline Telecommunications Organization & 28 & 20 \\
\hline Telecommunications Operator & 10 & 9 \\
Telecommunications Regulator & 16 & 5 \\
Academia, Research Centers, Equipment Providers & 5 & 13 \\
Total & $\mathbf{5 9}$ & $\mathbf{4 7}$ \\
\hline
\end{tabular}

\section{Scale Assessment}

\section{Factor Analysis}

An exploratory factor analysis (EFA) approach was conducted to explore groups of strategies. EFA was used as a validity check to make sure that the items did indeed measure the underlying latent variables 
that we had identified from theory. Nonparametric tests, such as the Friedman test, can be used on interval data. We used the Friedman's test to perform the rank-orders of Africa's stakeholders' perceptions. The Friedman test is the nonparametric equivalent of the ANOVA for repeated measures. Nonparametric tests are used when assumptions for parametric tests are not met. Those assumptions might include normal distribution and a large enough sample size. We therefore used the nonparametric equivalent of ANOVA because of the small sample size in some of the groups in the analyses. The criterion used for the factor analysis was the percentage of variance criterion. This criterion requires interpretation of the cumulative percentage of variance accounted for by the factor solution. The factors explaining a small percentage of the variance are deemed to be of little practical significance. In the social sciences it is common to consider a satisfactory solution as one that accounts for $60 \%$ of the total variance. The values of the Eigen values and percentage of variance indicate that it may be possible to factor the constructs to a smaller set of factors that could explain the phenomenon under study (Table 6).

Table 6: Eigen values and percentage of variance for the extraction of component factors.

\begin{tabular}{cccc}
\hline Factor & Eigen values & \% of Variance & Cumulative \% \\
\hline 1 & 7.841 & 26.138 & 26.138 \\
2 & 2.883 & 9.609 & 35.747 \\
3 & 2.394 & 7.980 & 43.727 \\
4 & 1.606 & 5.354 & 49.081 \\
5 & 1.573 & 5.244 & 54.325 \\
6 & 1.474 & 4.914 & 59.239 \\
7 & 1.178 & 3.928 & 63.167 \\
\hline
\end{tabular}

From the results above, it can be observed that the first seven factors accounted for more than $60 \%$ of the variance (Table 6). The Eigen values for the first seven factors were greater than or equal to 1 (Tables 6). Hence, the seven factors in each case could be used to summarize the groups of strategies (Green et al., 1997). Table 7 presents the factor loadings and Table 8 presents groupings of strategies.

Table 7: Rotated Factor Matrix.

$\begin{array}{rrrrrrr}\begin{array}{c}\text { Factor 1 } \\ \text { Loading }\end{array} & \begin{array}{r}\text { Factor 2 } \\ \text { Loading }\end{array} & \begin{array}{r}\text { Factor 3 } \\ \text { Loading }\end{array} & \begin{array}{c}\text { Factor 4 } \\ \text { Loading }\end{array} & \begin{array}{c}\text { Factor 5 } \\ \text { Loading }\end{array} & \begin{array}{c}\text { Factor 6 } \\ \text { Loading }\end{array} & \begin{array}{r}\text { Factor 7 } \\ \text { Loading }\end{array} \\ \text { Component } & 2 & 3 & 4 & 5 & 6 & 7\end{array}$




\begin{tabular}{|c|c|c|c|c|c|c|c|}
\hline Item 1 & 0.062 & -0.091 & -0.085 & 0.027 & -0.161 & 0.789 & 0.307 \\
\hline Item 2 & 0.132 & -0.152 & -0.107 & -0.136 & 0.226 & 0.555 & 0.300 \\
\hline Item 3 & 0.323 & 0.061 & -0.056 & 0.013 & 0.103 & 0.195 & 0.676 \\
\hline Item 4 & 0.026 & 0.263 & 0.570 & -0.336 & -0.132 & 0.185 & 0.390 \\
\hline Item 5 & 0.040 & 0.028 & 0.260 & -0.240 & 0.027 & 0.115 & 0.738 \\
\hline Item 6 & 0.093 & -0.091 & -0.094 & 0.836 & 0.007 & -0.072 & 0.021 \\
\hline Item 7 & 0.141 & -0.027 & 0.085 & 0.700 & 0.118 & -0.120 & -0.127 \\
\hline Item 8 & 0.213 & 0.206 & 0.224 & 0.081 & 0.694 & 0.023 & 0.100 \\
\hline Item 9 & 0.101 & 0.043 & 0.039 & 0.218 & 0.701 & -0.079 & 0.058 \\
\hline Item 10 & 0.167 & 0.121 & -0.154 & -0.454 & 0.598 & 0.071 & 0.006 \\
\hline Item 11 & 0.609 & 0.219 & 0.383 & -0.182 & 0.174 & 0.028 & -0.047 \\
\hline Item 12 & 0.453 & 0.366 & 0.052 & -0.153 & 0.413 & 0.133 & 0.040 \\
\hline Item 13 & 0.150 & -0.056 & 0.187 & -0.301 & 0.098 & 0.041 & 0.046 \\
\hline Item 14 & 0.467 & 0.076 & 0.432 & -0.185 & -0.156 & 0.457 & -0.124 \\
\hline Item 15 & -0.078 & 0.335 & 0.308 & -0.109 & 0.011 & 0.542 & -0.196 \\
\hline Item 16 & 0.389 & 0.351 & 0.100 & 0.050 & 0.141 & -0.165 & $.427 * *$ \\
\hline Item 17 & 0.171 & 0.157 & 0.545 & -0.021 & 0.395 & -0.193 & -0.055 \\
\hline Item 18 & 0.308 & -0.059 & 0.662 & 0.210 & 0.028 & 0.029 & 0.158 \\
\hline Item 19 & 0.395 & 0.195 & 0.634 & -0.013 & 0.087 & -0.032 & 0.097 \\
\hline Item 20 & 0.511 & 0.354 & 0.250 & 0.047 & 0.166 & 0.017 & 0.077 \\
\hline Item 21 & 0.649 & -0.100 & 0.233 & 0.033 & 0.182 & -0.343 & -0.022 \\
\hline Item 22 & 0.813 & 0.134 & 0.113 & 0.185 & 0.018 & 0.189 & 0.201 \\
\hline Item 23 & 0.679 & 0.076 & 0.053 & -0.150 & 0.087 & 0.494 & -0.101 \\
\hline Item 24 & 0.078 & 0.854 & -0.051 & -0.061 & 0.157 & -0.027 & -0.105 \\
\hline Item 25 & 0.240 & 0.813 & 0.128 & -0.030 & -0.010 & -0.032 & 0.183 \\
\hline Item 26 & 0.097 & 0.775 & 0.146 & 0.048 & 0.149 & 0.050 & 0.088 \\
\hline Item 27 & 0.669 & 0.012 & 0.163 & 0.365 & 0.188 & 0.044 & 0.174 \\
\hline Item 28 & 0.211 & 0.150 & 0.284 & 0.525 & 0.288 & 0.282 & -0.143 \\
\hline Item 29 & 0.798 & 0.076 & 0.103 & 0.083 & 0.232 & 0.078 & 0.145 \\
\hline Item 30 & 0.715 & 0.252 & 0.121 & 0.005 & 0.007 & -0.027 & 0.360 \\
\hline
\end{tabular}

Notes: Extraction Method: Principal Component Analysis. Rotation Method: Varimax with Kaiser Normalization. Rotation converged in 16 iterations.

** Due to this very low factor loading (.427) the corresponding item was dropped. 


\section{Naming the Factors}

Given the factor loadings in Table 7, the authors did the following to name the factors:

1. We revisited the literature to see possible names that could closely explain the items that loaded under each corresponding factor;

2. Given that several possible factor names emerged from the literature, the authors brainstormed and carefully examined the wordings of each item under the corresponding factors. From the brainstorming, we chose factor names from the literature that most closely explained the items.

3. With further review by non-authors of the paper we refined and emerged with the factor names listed in Table 8 below.

Table 8: Groups of Strategy that Emerged from Exploratory Factor Analysis

\section{Factor 1: Investment in ICTs}

Africa's LDEs, with assistance of funding organizations, should set up
long-term contracts to buy new knowledge from developed countries (i.e. advocate for joint ventures).

Countries and international agencies with development assistance programs should give higher priority to growth of teledensity in Africa's LDEs.

Funding institutions must ease conditions to grant loans for the purpose of establishing basic telecommunications infrastructure in Africa's LDEs.

Encourage private investments through the reorganization of the sector and by using policy to direct investment into the sector.

Encourage the participation of foreign private investors in funding directed towards growth of teledensity.

Telecommunications service carriers in rural areas should be provided easy loan requirements, lower taxes, and ease to register such businesses.

Encourage private investors to establish pay phone services such as public telephone booths.

Encourage private investors to establish tele-centres or shared community access in order to promote use of telephone services and other forms of shared access, which could in turn promote use of advanced services such as the Internet

Factor 2: Wireless and Satellite Infrastructure

Mobile satellite services and fixed cellular networks should be installed.

Use satellites to provide telecommunications in Africa's LDEs due to the ubiquitous coverage offered by satellite technology.

Use semi-fixed analog mobile phone cells placed in communities without telecommunications along with cheap handsets and a VSAT link to regional hubs. 


\section{Factor 3- Government Policy}

Establish an impartial, non-governmental regulatory body to control the telecommunications industry.

Africa's LDEs governments should subsidize the local telecommunications industry in order to expand their turnover and employment.

To save cost of equipment purchase, Africa's LDEs should consider pooling their purchases of commonly used equipment including terminals and components.

Encourage growth in the service sector (tourism, transportation, etc), which will be a major source of income that can in turn increase the provision for more phones.

\section{Factor 4-Government Regulation}

Establish an impartial, governmental regulatory body to control the telecommunications industry.

Establish an impartial, governmental regulatory body to set and uphold standards within the telecommunications industry.

Mandate that new service providers serve both urban and rural areas, using resources of urban areas to subsidize rural areas.

Factor 5: Building Local Capacity

Africa's LDEs should review the possibilities for local or regional manufacture of telecommunications equipment.

Operators and manufacturers should enhance the training opportunities they offer to telecommunications staff of Africa's LDEs.

Africa's LDEs should be trained to carry out monthly routine maintenance of already existing equipment.

Factor 6: Privatization

Turn the telecommunications operator into an independent company with complete autonomy.

Sell shares of the telecommunications operator to the public.

\section{Factor 7: Policy/Regulation}

This factor was dropped because of its very low Cronbach alpha (see section that follows for details).

Encourage competition among the telecommunications operators.

Establish an impartial, non-governmental regulatory body to set and uphold standards within the telecommunications industry.

Devote 1 to 2 percent of GNP to telecommunications investment. 


\section{Reliability}

Cronbach's alphas were computed for all items together and for each factor under all seven dimensions of strategies that emerged from our exploratory factor analysis: Investment in ICTs, Wireless and Satellite Infrastructure, Government Policy, Government Regulation, Building Local Capacity, Privatization, and Policy/Regulation (Table 9).

Table 9: Cronbach Alphas

\begin{tabular}{|l|l|}
\hline Factor & Cronbach's Alpha \\
\hline Investment in ICTs & 0.862 \\
\hline Wireless and Satellite Infrastructure & 0.800 \\
\hline Government Policy & 0.634 \\
\hline Government Regulation & 0.680 \\
\hline Building Local Capacity & 0.618 \\
\hline Privatization & 0.600 \\
\hline Policy/Regulation & $0.498^{*}$ \\
\hline
\end{tabular}

*The Policy/Regulation factor was dropped due to low Cronbach's alpha

The generally agreed upon lower limit for Cronbach's alpha is .60 (Robinson et al., 1991); hence, we believed six out of the seven factors were suitable to use in our study. Essentially, these values provided evidence of internal consistency among their respective items.

We classify these variables as reflective factors instead of formative since the items that make each one up are highly related to each other and the overall factors have high reliability. This is obvious from our exploratory factor analysis and our Cronbach's alpha test. The items for the factors seem to share a common theme and dropping one item in a factor does not seem to alter the conceptual domain of the factor. The items in each factor are expected to covary with each other.

Given the evidence of internal consistency, we proceeded to investigate the rank order of the remaining six strategies so we can have a sense of how the African Stakeholders perceived their impact. The section that follows presents our findings from the rank order, using Friedman's Test. 


\section{Results from Rank Order of Six Strategies}

Mean value and standard deviation were computed for each factor. The results of the rank order of the means revealed that the "investment in ICT" factor was ranked the highest, followed by the "Wireless and Satellite Infrastructure" factor. The "Privatization" factor was ranked the lowest. Table 10 shows the rank orders of the mean scores for the six factors.

Table 10: Africa LDE Stakeholders' Rank Order $^{2}$ of Means

\begin{tabular}{|l|l|l|l|l|l|}
\hline Rank & Factor & Mean Rank & Mean & $\begin{array}{l}\text { Standard } \\
\text { Deviation }\end{array}$ & $\begin{array}{l}\text { Number of } \\
\text { Items }\end{array}$ \\
\hline 1 & Investment in ICTs & 3.98 & 6.02 & 0.98 & 8 \\
\hline 2 & Wireless and Satellite Infrastructure & 4.09 & 5.97 & 1.17 & 3 \\
\hline 3 & Government Policy & 2.55 & 5.01 & 1.30 & 4 \\
\hline 4 & Government Regulation & 2.55 & 4.64 & 1.66 & 3 \\
\hline 5 & Building Local Capacity & 4.05 & 5.86 & 1.07 & 3 \\
\hline 6 & Privatization & 3.77 & 5.58 & 1.30 & 2 \\
\hline
\end{tabular}

$\varkappa^{2}=75.002 ;$ d.f. $=5 ;$ Significance $=.000^{++}$

\section{Differences of Perceptions}

Our second research question is to determine whether there exist any differences in the perceptions of governmental stakeholders (GSH) as compared to non-governmental stakeholders (NGSH). Since in our research question we are only concerned about differences between GSH and. NGSH, we ran an ANOVA on all six strategies to see differences between both groups and not between the affiliations. From the analyses, we found that stakeholders differed in their perception on three out of the six strategies.

\footnotetext{
${ }^{2}$ The rank order of each category of strategies was evaluated using Friedman's Test (Kerlinger, 1986, $\mathrm{p} 271$ ). This is a more direct evaluation of the investigator's research question or hypothesis that involves the association of the ranks. The Friedman's Test therefore tests the null hypothesis that $\mathrm{k}$ related variables come from the same population. For each case, the $\mathrm{k}$ variables are ranked from 1 to $\mathrm{k}$. The test statistic is based on these ranks. Each case is a judge or rater and each variable is an item or person being judged. In this case, each stakeholder was a rater of each factor (strategy) and its associated items. The null hypothesis states that there is no difference in mean ranks (the sum of ranks divided by the number of cases) of the stakeholders perceptions while the alternative hypothesis states that a difference exists in the mean ranks of the stakeholders perceptions.

The test statistic for the Friedman's test is a Chi-square $\left(\mathcal{X}^{2}\right)$ with a-1 degrees of freedom (d.f.), where 'a' is the number of repeated measures. When the p-value (Significance) for this test is small (usually $<0.05$ ) you have evidence to reject the null hypothesis.
} 
We observe that there is a significant difference in stakeholders' perceptions of the strategies. As a result of this, stakeholders did differ in their perceptions depending on whether they were governmental stakeholders or non-governmental stakeholders. The result of the ANOVA for the effect of Group is shown in Table 11.

Table 11: ANOVA results for the effect of Group

\begin{tabular}{|c|c|c|c|c|c|c|}
\hline Factor & Effect & D.F. & $\begin{array}{l}\text { Sum of } \\
\text { Squares }\end{array}$ & Mean Square & $\mathrm{F}$ & Significance \\
\hline $\begin{array}{l}\text { Investment in } \\
\text { ICTs }\end{array}$ & $\begin{array}{l}\text { Affiliation } \\
\text { Group } \\
\text { Interaction }\end{array}$ & $\begin{array}{l}1 \\
98 \\
99\end{array}$ & $\begin{array}{l}3.752 \\
92.197 \\
95.949\end{array}$ & $\begin{array}{l}3.752 \\
.941\end{array}$ & 3.988 & $.049 *$ \\
\hline $\begin{array}{l}\text { Wireless and } \\
\text { Satellite } \\
\text { Infrastructure }\end{array}$ & $\begin{array}{l}\text { Affiliation } \\
\text { Group } \\
\text { Interaction }\end{array}$ & $\begin{array}{l}1 \\
98 \\
99\end{array}$ & $\begin{array}{l}.944 \\
135.167 \\
136.111\end{array}$ & $\begin{array}{l}.944 \\
1.379\end{array}$ & .684 & .410 \\
\hline $\begin{array}{l}\text { Government } \\
\text { Policy }\end{array}$ & $\begin{array}{l}\text { Affiliation } \\
\text { Group } \\
\text { Interaction }\end{array}$ & $\begin{array}{l}1 \\
99 \\
100 \\
\end{array}$ & $\begin{array}{l}6.602 \\
161.580 \\
168.182 \\
\end{array}$ & $\begin{array}{l}6.602 \\
1.632\end{array}$ & 4.045 & $.047 *$ \\
\hline $\begin{array}{l}\text { Government } \\
\text { Regulation }\end{array}$ & $\begin{array}{l}\text { Affiliation } \\
\text { Group } \\
\text { Interaction }\end{array}$ & $\begin{array}{l}1 \\
96 \\
97 \\
\end{array}$ & $\begin{array}{l}1.749 \\
265.512 \\
267.261 \\
\end{array}$ & $\begin{array}{l}1.749 \\
2.766\end{array}$ & .632 & .482 \\
\hline $\begin{array}{l}\text { Building } \\
\text { Local } \\
\text { Capacity }\end{array}$ & $\begin{array}{l}\text { Affiliation } \\
\text { Group } \\
\text { Interaction }\end{array}$ & $\begin{array}{l}1 \\
100 \\
101\end{array}$ & $\begin{array}{l}10.180 \\
105.473 \\
115.653\end{array}$ & $\begin{array}{l}10.180 \\
1.055\end{array}$ & 9.652 & $.002 * *$ \\
\hline Privatization & $\begin{array}{l}\text { Affiliation } \\
\text { Group } \\
\text { Interaction }\end{array}$ & $\begin{array}{l}1 \\
103 \\
104 \\
\end{array}$ & $\begin{array}{l}.009 \\
175.139 \\
175.229 \\
\end{array}$ & $\begin{array}{l}.009 \\
1.700\end{array}$ & .053 & .818 \\
\hline
\end{tabular}

$\mathrm{P}<0.05 ; * * \mathrm{p}<0.01 ; * * * \mathrm{p}<0.001$

Compared to the NGSH, the GSH were stronger in their perception of the factors "Investment in ICTs," "Government Policy," and "Building Local Capacity". For the "Investment in ICTs" factor, the mean for the GSH and NGSH was 6.19 and 5.80, respectively; for the "Government Policy" factor, the means for the GSH and NGSH was 5.24 and 4.72, respectively; and for the "Building Local Capacity" factor, the mean for the GSH and NGSH was 6.15 and 5.52, respectively. (See Table 12 below). 
Table 12: Means for Governmental and Non-Governmental Stakeholders

\begin{tabular}{|l|c|c|}
\hline \multicolumn{1}{|c|}{ Factor } & $\begin{array}{c}\text { Mean; } \\
\text { Governmental Stakeholders }\end{array}$ & $\begin{array}{c}\text { Mean; } \\
\text { Non-Governmental } \\
\text { Stakeholders }\end{array}$ \\
\hline Investment in ICTs & $\mathbf{6 . 1 9}$ & $\mathbf{5 . 8 0}$ \\
\hline Wireless and Satellite Infrastructure & 5.88 & 6.07 \\
\hline Government Policy & $\mathbf{5 . 2 4}$ & $\mathbf{4 . 7 2}$ \\
\hline Government Regulation & 4.76 & 4.50 \\
\hline Building Local Capacity & $\mathbf{6 . 1 5}$ & $\mathbf{5 . 5 2}$ \\
\hline Privatization & 5.61 & 5.55 \\
\hline
\end{tabular}

\section{DISCUSSION}

Although the rank order reveal that some factors were ranked much higher than others, it is worth noting that all six factors that emerged from our exploratory factor analysis had relatively high mean values. This shows that the stakeholders felt strongly about the strategies. For that reason, we will discuss all six factors in the section that follows and also discuss the differences in perceptions as revealed through the ANOVA results.

\section{Investment in ICTs}

This strategy was ranked highest. Investment in ICTs is undoubtedly a cornerstone for telecommunication growth in any country (Meso et al., 2005, Okoli, 2003). A major problem in Africa's LDEs is low level of investment and skepticism on the part of locals and foreign investors respectively. Foreign investors fear putting their resources at risk. As for the locals, there is an apprehension in taking risk (an inevitable characteristic of investment). These findings conform to other findings in existing literature for developing economies in general. Maddy (2000) identified two breeds of investors for LDEs: Do-Gooders and Do-Wellers. Do-Gooders are investors and lenders that are typically quasi-government agencies (though some are multinational banks) that provide equity capital and loan capital for ostensibly idealistic purposes; generating economic prosperity in emerging-market countries and stimulating further influx of capital from other investors. They generally do not embrace the fundamental idea of reward for risk that underlies entrepreneurship. 'The do-good' venture capitalists are staffed with career bureaucrats who stand to gain nothing if their agencies' investments do well. 
Do-Wellers are the classic, hungry, "show me the money" investors, who believe business is a highstakes game. They may like worthy causes, but "doing good" is not a major concern. They are generally savvy financiers who understand that high risk is needed for high returns.

In highly ranking investment in ICTs, the stakeholders contend that Africa's LDEs should follow the Do-Wellers' approach. In order to do this, the Africa's LDEs should encourage private investment through the reorganization of the telecommunication sector and by using policy to direct investment into the sector. Such an approach will encourage entrepreneurism in the technology sector, which is the basic philosophy behind the Do-Wellers' approach.

Secondly, the stakeholders say that these countries should encourage the participation of foreign private investors in funding projects directed towards growth of technological infrastructure for telecommunication diffusion in Africa's LDEs. Countries such as Eritrea and Somalia have the major challenge of attracting capital by restructuring their telecommunication sector. Africa's LDEs must create an environment to attract private investors. A stakeholder commented:

"I think we have a lot of local investors with the capital to invest but if the right investment environment is not created, not even the foreign investors will invest. If the right environment is created, preference should be given to the local private investor than the foreign investor."

Several African countries have taken the extra step to encourage private investment in telecommunication services. Examples include Botswana, The Gambia, and Tunisia. These countries have experienced tremendous growth in telecommunication usage at the rate of $15 \%$ and above per year.

Africa's LDEs, with assistance of funding organizations, should set up long-term contracts to buy new knowledge from developed countries, that is, advocate for joint ventures. Also, development organizations should conduct seminars to improve the qualifications of experts of Africa's LDEs. Such an alliance could be the basis of a (long term) transition to greater self-sufficiency with less dependence on foreign countries. 
The stakeholders argue that countries and international agencies with development assistance programs should give higher priority to growth of telecommunication in Africa' LDEs. Also, funding institutions must ease conditions to grant loans for the purpose of establishing basic technological infrastructure in Africa"'s LDEs. Related to this factor the ITU has set up a private sector driven by a multinational and development funding organization called WorldTel. This organization focuses exclusively on the development of telecommunication and IT in LDEs. WorldTel provides client LDEs with direct equity investment acquired from private financial investors in the world and coordinate project finance, from debt and equity coming from governments, telecommunication operators and manufacturers. It also helps client countries improve their policies and management practices. A stakeholder cautions on continuous dependence on foreign donors:

"Concerning the issue of donor inflows to the telecom (sector) we must be very careful with the conditions attached to the terms of the grant...."

It is crucial to mention that, the ability of a lagging country to absorb the more advanced technologies, is dependent on its social capacity which involves various aspects of the country's development process. Technological catching-up is often associated with innovative activities such as R\&D and patenting. On the other hand, capital investment is necessary to import the more advanced technology that is embodied in the new equipment. Besides innovation and investment, the level of education also plays a crucial role in determining the technical competence of the labour force. Also, Sub-Saharan African countries should develop the factors required to attract foreign direct investment, in adequate match with foreign companies' strategies. Policies supporting the national systems of innovation and encouraging technology diffusion are capital to this end, because, they contribute to the creation of assets.

The stakeholders also encourage other financial and investment strategies such as the push for investors to establish telecommunication services in rural areas and other underserved communities. They encourage investments such as; establishing public telecommunications access( telecenters). Note that this is an extremely important strategy for most LDEs as these countries are generally about $70 \%$ rural. Investors have typically ignored these rural areas for the sake of profit in urban areas. However, as of 
January 2007, there have been reports of unprecedented surges in demand for telecommunication services in rural areas. Investors can greatly benefit from such a surge and also help the neglected communities get connected to the rest of the world (M'Sene, 2007).

\section{Wireless and Satellite Infrastructure}

"An excited Edwin Ireri smiled broadly as he handled his first mobile phone. For the first time in his life, the Kenya Railways inspector could now communicate with his bosses, employees and family at will. Ireri knows the cell phone will change his life but doesn't quite grasp how people like him are changing the nature of the telecom industry." (Tomlinson, 2002).

The statement above represents a phenomenon reminiscent of many success stories vis-à-vis the exponential growth in multiple dimensions of wireless telecommunication infrastructure in Africa's LDEs. It is also good news to many foreign investors now flooding the region with new businesses that would have otherwise been difficult to establish and run without the appropriate telecommunication infrastructure.

By ranking the wireless and satellite infrastructure factor very high, the stakeholders believe that in order to overcome the geographical-oriented obstacles, Africa's LDEs should install mobile satellite services and fixed cellular networks. In essence, the use of satellites would provide faster and broader telecommunication access in Africa's LDEs due to the ubiquitous coverage offered by satellite technology (Meso et al., 2005). Also, Wireless and Satellite Infrastructure in this context includes the use of semi-fixed analog mobile phone cells placed in communities without telecommunication access and a VSAT link to regional hubs.

The implementation of cellular telephony to create wireless local loops, as an alternative to wired systems, is receiving increasingly favorable reviews, especially in developing economies. The reasons are compelling: dramatically lower line cost, improved reliability, and greatly enhanced flexibility. Developing economies in South East Asia, Eastern Europe, and Latin America are increasingly turning to cellular to provide basic telephone services. There are predictions that basic telephony will migrate to cellular and other advanced wireless technologies, while legacy wired systems would be dedicated for data services. Furthermore, with advanced cellular technology, people can do various electronic market transactions using 
their cellular phones, as is the case in most Scandinavian countries. Some stakeholders expressed skepticism. For example, one among the skeptics commented:

"Wireless communication is the order of the day so I think we should pursue it because of the advantages it has over the wire system. I also think we should give preference to digital technology since it has advantages over the analog system."

While we can speak of the utility of wireless technology, the unresolved question is how to bring this technology to the average citizen of an Africa's LDEs--not forgetting the provision of such services in rural areas. A couple of the stakeholders had these to say:

"Though I strongly agree on the suggested approaches above (the adoption of wireless technologies), one thing I'll like to point out is the cost factor. We are actually in a dilemma. It's a waste, to install complex wireless communication systems in some rural areas, where they are very underutilized, but at the same time, we want to ensure that those in the rural areas can communicate without such complex systems. If the resources were available, those in the rural areas would most likely opt for some other thing; such as; electricity, water, hospitals, schools, etc."

"All the suggested options (the adoption of wireless technologies) may solve the problem, but this is subject to the pricing of the service."

Although teledensity has traditionally only regarded land-based telephone lines, with the rapid adoption of wireless telecommunications' media such as cellular telephony and VSAT, this concept will need to be expanded to include other measures of telecommunications intensity. The research to date has almost exclusively employed the traditional measurement that considered only landlines. Traditional teledensity counts the number of landlines, whereas a contemporary calculation would consider each mobile telephone subscription to be a wireless "line". While Africa's LDEs' landline teledensity doubled from 0.4 lines per 100 citizens in 1991 to 0.9 per 100 in 2002, the mobile teledensity moved from virtually zero in 1991 to 1.9 mobile phone subscriptions per 100 citizens in 2002. Many of these are digital connections, which pave the way for access to ICT in countries where most citizens cannot afford personal computers. Today, wireless communications seems more relevant than wired means for the development of Africa's LDEs' data communications networks. 
Wireless telecommunications infrastructure-once the preserve of the rich Western elite-is permeating the world's poorest countries, where they are least expected. The African continent has become one of the world's biggest birthing grounds for the wireless telephone industry. By the end of 2004 over two-thirds of the region's countries - had more mobile than fixed subscribers; a higher percentage than any other continent (International Telecommunications Union, 2004). Africa's LDEs accounts for a teledensity of about 0.79 and a mobile density ${ }^{3}$ of 1.13 .

The number of mobile subscribers in 30 Africa's LDEs rose from zero in 1996 to over 51 million in late 2004. The rate of growth for the entire continent has been more than 82 percent a year, much faster than 33 percent growth rate in the Americas. In many countries, such as Cameroon, Kenya, Senegal and Tanzania, annual cellular growth rates are running in excess of 300 percent. Furthermore, the total number of cellular phone users still remains very low although the rate/rhythm of adoption is high. The rate/rhythm of adoption of an innovation can be defined as the speed to which it is adopted within a given population and it is measured by number of individuals per unit of time (Rogers, 1995).

These wireless technologies are tremendously contributing to the economic development of Africa's LDEs to improve delivery of education through tele-education (Mbarika and Mbarika, 2006); improvement of commerce through m-commerce (Kaba et al, 2008; Meso et al., 2005); and delivery of healthcare through e-medicine (Sood et al, 2008; Kifle et al., 2008). These instrumental uses of the mobile phone represent ways in which mobile phones, in low-teledensity settings, are operated in manners normally attributed to landlines. Thus, wireless communications seem to be an excellent alternative to landlines, and a major contribution to the resolution of teledensity problems in Africa's LDEs.

\section{Government Policy}

With the Government Policy strategy, the Stakeholders promote privatization to go hand-in-hand with non-governmental regulation which involves establishing an impartial, non-governmental regulatory body to control the telecommunications industry. This also involves establishing an impartial, non-governmental

\footnotetext{
${ }^{3}$ Mobile Density is the total number of mobile phone subscribers per 100 persons.
} 
regulatory body to set and uphold standards within the telecommunications industry. Such a move may reduce the level of corruption that already exists within the regulatory sector (governmental) that currently exists in most LDEs. There may, however, be some telecommunications competition and universal coverage concerns that may need some level of government regulation. These are discussed in the next section under the "Government Regulation" factor. Also the stakeholders concurred that a good strategy would be to mandate that new service providers serve both urban and rural areas, using resources of urban areas to subsidize rural areas and also extend their turnover and employment opportunities for the broader populace of these nations. The stakeholders also encouraged pooling purchases of commonly used equipment including terminals and components in a bid to save costs of equipment purchase. While this does not sound bad, the challenge is to get African LDEs to agree on basic issues. However, as of June 2007, some African LDEs started to reorganize themselves in economic zones so as to share resources such as those involved in telecommunications. One of such zones is the East African Community that includes the nations of Kenya, Tanzania, Uganda, and more recently the previously war torn nations of Burundi and Rwanda. In a recent visit by one of the co-authors to Rwanda, signs of progress in telecommunications were very apparent for both land lines and wireless infrastructures. In fact Rwanda is one of the few African countries with its own Internet Exchange Point (IPX) which will eventually be shared by other members of the East African Community of nations. Although these East African nations are not necessarily rich in natural resources, they are strongly encouraging growth of their service sectors, in terms of tourism especially. This is acting as a strong catalyst to the growth of telecommunication of these nations so as to attract more tourists.

\section{Government Regulation}

The stakeholders strongly encourage government regulation. With this factor, the stakeholders strongly feel that in addition to non-governmental regulation (discussed in the previous section), there should be a corresponding level of governmental regulation to direct some aspects of the telecommunications industry and to uphold standards set within the industry. This helps create the necessary checks and balances

needed for fair play in the telecommunications sector. Just as governments have abused power in these 
LDEs, leaving the telecommunications industry entirely in private hands may lead to acute abuse of power by the big name investors (usually from foreign countries), hence killing the average small scale investors (usually the locals). Converse to the case of developed nations where the "little guy" ca sue the "big guy" and have their voices heard in court, LDEs do not really have strong legal systems to allow for that. Even more important, regulation enables the government to impose strict laws about universal service, especially when private investors get involved in the telecommunications sector. Typically these investors will not want to establish a presence in rural areas in Africa's LDE, given that services in such areas are hardly profitable. However, most Africa's LDEs have about $70 \%$ of their population in rural areas. Government regulations to push private telecommunications investors to establish a presence in these rural regions will provide a platform for the rural populace to reach out to other parts of their country and the world. For example farmers in these areas will be able to communicate with clients in the urban parts of the country providing new outlets to sell their produce. This is already happening in Cameroon where wireless (cell) towers have been established in rural areas (M'Sene, 2007). Most of these areas have never had a single land-line but today communications is very possible through wireless loops due to government regulations that have pushed local and foreign investors to establish a wireless presence in the rural regions (usually as a condition for the government to grant wireless operating licenses).

\section{Building Local Capacity}

The International Development Research Center (IDRC) pointed to the over-dependence of most Africa's LDEs on foreign technicians and consultants in the maintenance of technological infrastructure and the development and enactment of key telecommunications policy guidelines respectively (Mbarika et al., 2005). The IDRC notes; this has contributed to the formulation of policies that do not adequately address the real needs of these countries. Thus the need to utilize and further develop the capacities of local technical experts in the field of telecommunications is of prime importance to the chances of creating sustainable development. 
Africa's LDEs should review the possibilities for local or regional manufacturers of telecommunications related equipment, and that operators and manufacturers should enhance the training opportunities they offer to telecommunications related staff of Africa's LDEs. Furthermore, Africa's LDEs should be trained to carry out monthly routine maintenance of already existing equipment.

Regarding local manufacturing, one of the strategies that have accelerated growth of telecommunications in Indonesia is the promotion of local industries. In fact, Indonesia began to export other telecommunications related products. Local manufacturing capability would ensure rapid development of telecommunications related services in LDEs (Meso et al., 2007). This could be a step to remove Africa's LDEs from their current over-dependence on foreign countries.

Further, African LDEs should review the possibilities for local or regional manufactures of telecommunications equipment, and that operators and manufacturers should enhance the training opportunities they offer to telecommunications staff of these countries. Locals should be trained to carry out monthly routine maintenance of already existing equipment. Two stakeholders commented:

"I think this issue of the foreign countries helping us should be in the short term since they have it now and we must learn and be able to start doing it on our own and become independent."

"Training should be an integral part of any equipment installation replacement. Foreign experts should be used to assist in the process and assist in contract specifications."

The stakeholders strongly discourage any form of total foreign dependency. Essentially, Africa's LDEs should not always rush to hire foreign experts to perform routine maintenance of already existing equipment. Over-dependency on foreign experts has been the trend in most Africa's LDEs (Mbarika et al., 2005). Furthermore, the preference for foreign experts is symptomatic of the lack of confidence of African technical experts, administrators and policy-makers in their own (national) professionals.

Concerning total foreign dependency, one stakeholder had the following to say:

"The problem of African countries is mainly the transfer of technology and know-how to their nationals. 'Black-box' moving and dependency on expatriates to do the maintenance will not help to develop the necessary know-how among the nationals for the development and maintenance of the systems, this expertise that won't be affected by the local conditions in African countries of poverty or other unfavorable conditions and won't fly away under the first sign of political turbulence. Thus, I believe in the importance of transfer of technology and know-how to nationals as a step towards sustainable development, and I also believe that intra-African co-operation can lead to better results in negotiating the transfer of technology." 
The apprehension towards total foreign dependency was even more interesting when compared to the high ranking for investments in ICTs (which largely includes foreign investments). The African stakeholders are essentially saying to the West "we need your money, but not your control of the technology industries."

\section{Privatization}

Looking at the fairly high means for the privatization factor, the stakeholders are essentially saying that the telecommunications operators that provide telecommunications connectivity should be turned into an independent company with complete autonomy, and that shares of the telecommunications operator should be sold to the public. Furthermore, the stakeholders believe that Africa's LDEs should encourage competition among the telecommunications operators as a major step to solve the organizational-oriented obstacles. As far back as the 70s, Littlechild (1978) stated that private ownership was positively correlated to a country's growth in most dimensions of its telecommunications sector. In support of that theory, the number of lines available for telecommunications connectivity significantly increased in Argentina, Chile, Mexico, and Malaysia after privatization (Mbarika et al, 2005). Similar results to boost telecommunications in LDEs could be expected if privatization is followed in these countries.

Privatization therefore seems to be a major factor under the organizational- oriented strategy. A stakeholder explained it like this:

"Privatization is one important step to combat organizational and policy-oriented obstacles. Private companies operate in competition, and service quality is bound to be high. However, given that privatization strips most powers off the monopolistic state machinery in some countries, it is not surprising that there is a lot of resistance to this option. It is not an exaggeration to say that one can find a state-owned enterprise with a very high running cost, yet this enterprise cannot be privatized. And even when it is done, it's probably not being done in a transparent manner. Nevertheless, given the global trends of business activities, privatization would be understood in the long run."

Privatization of the technological infrastructure sector has greatly improved the levels of telecommunications activity in several developing economies such as the Philippines, Chile, and South Africa. Within Africa's LDEs there exist several examples of how privatization of the sector improved the levels of telecommunications access. For example in Botswana, separation of the Public Telecommunication 
Operator (the Botswana Telecommunications Corporation) from the State in 1980 accounted for a teledensity of 3.1 lines per 100 people, the third highest in Africa's LDEs. The technological network has grown at a rate of 20 percent per year since 1987. More and more people and businesses in Botswana now have telecommunications access. In The Gambia, one of the reasons for its success is that the process of "corporatization," or separation of the operator from the state, took place relatively early (Mbarika, 2001). The main telecommunications access provider, GAMTEL, was established as a private limited company under the Companies Act in March 1998. As such, The Gambia has found it easier than other telecommunications operators supporting telecommunications activities in Africa to attract funds for investment (Mbarika, 2001).

\section{Differences in Perceptions between Governmental (Internal) and Non-Governmental (External) Stakeholders}

There are significant differences between the strength of response of governmental stakeholders (GSH) as compared to non-governmental stakeholders (NGSH) in the areas of Investment in ICT, Government policy and Building Local Capacity. GSH seem to pay great attention on these factors than NGSH. We believe these differences are related to governmental stakeholders' role which is to provide a vision, a strategy and an enabling environment to develop the national information and communication infrastructure within their countries.

Earlier in the paper we presented Table 11 (ANOVA) and Table 12 (Descriptive Statistics) to show the difference between these two groups of stakeholders. For the "Investment in ICTs" factor, the mean for the GSH and NGSH was 6.19 and 5.80, respectively. The GSH feel stronger than the NGSH in attracting investors for their telecommunications sector. This was kind of surprising as one would expect the reverse. However, these governments have come to realize after about 40 years of independence from the "West" that they are strictly limited in resources to be able to control the telecommunications sector by only using their meager resources. Hence they are turning to private investors. With the wind of democracy sweeping the 
African region, many of the newly elected governments are creating the environment needed for investors to feel comfortable and secure to invest in these countries.

For the "Government Policy" factor, the means for the GSH and NGSH were 5.24 and 4.72, respectively. Here the GSH feel even stronger than the NGSH in having some level of involvement in the telecommunications sector so as to ensure fair game in the competitive field of telecommunications. Further, these GSH want to strongly push for rural telecommunication development through establishing a universal assess policy to cater for their largely rural populace. While NGSH seemingly encourage some level of governmental intervention, they see to strongly want the competition game to go as the profitability goes; not necessarily putting particular emphasis to developing rural telecommunications.

As for the "Building Local Capacity" factor, the mean for the GSH and NGSH was 6.15 and 5.52, respectively. Again the GSH felt much stronger about this factor than the NGSH. Similar to the "Investment in ICTs" factor, the GSH have come to realize the need to build local capacity and not for them to try to do all the work. We believe we would have had a different reaction from the GSH if we had performed this research 10-15 years ago when most of the governments were mainly dictatorial, controlling almost every sector of the economies of these nations. Today, most African LDEs are seeking aid from the "West" not in terms of money mainly but in terms of training locals. Hence, some countries such as Cameroon have a governmental policy of tax relief for educational institutions so as to encourage local capacity building. This has resulted in plethora of tertiary institutions of training in the information technology and telecommunications area. Many of these institutions in Africa have created alliances with US and European technology companies such as Microsoft and Cisco; hence, offering certifications from these world renowned companies.

\section{RESEARCH CONTRIBUTIONS}

Over the years Africa has been portrayed as a problematic continent in almost every aspect of social, economic and political life. The world in general and the news media in particular has found it to be very interesting to talk about Africa's problems. However, very little has been done in the way of finding 
applicable solutions for these problems. Unfortunately, the same seems to apply in the academic community.

In effect, the results could assist governments and large international ICT coordination agencies in their search for a solution to build an information-based society. An information-based society is often defined as a world in which everyone has the possibility to create, obtain, use and share information and knowledge, and in which individuals, communities and populations can realize the totality of their potential and make long-lasting improvements in their quality of life. New information and communication make possible instant exchanges of information and the realization of ground-breaking applications, for example in the fields, of public administration, commerce, education and health care to name a few.

In order to attain a true information-based society and permit the Africa's LDEs to profit from opportunities offered by communications technologies, it is important to understand the strategies for their development. This study has allowed us to define the relevant strategies which could be leveraged for more efficiency and effectiveness. The study thus suggested strategies as well as an alternative solution, namely wireless communication to overcome the low teledensity problem.

The results of this study indicate that the governments and the organizations concerned with the promotion of the telecommunications sector in Sub-Saharan Africa should take into account the divergent interests of the stakeholders concerned when formulating and implementing their policies. They should also support and develop mobile communications which, from all indications seems to have found a great response in urban as well as rural African populations. We believe this will surely contribute to the universal access to communications services, particularly with the prospects of the new applications described previously. Moreover telecommunications policies should find the incentives needed to attract foreign investment in support of the privatization in this sector, for example in partnerships between foreign companies with proven expertise in the area and national investors. 


\section{CONCLUSION}

Several attempts in the engineering management literature to investigate technology transfer, diffusion and adoption at the national, organizational and individual levels have yielded interesting, albeit different findings (M'Sene, 2007; Jelinek \& Markham, 2007; Loch et al., 2003; Khan \& Emdad, 1992; Soedarsono et al., 1998). We attempt to study these differences and similarities by integrating theory with practitioners' (ATS) insights of viable strategies, so as to develop our understanding of this under researched topic and region of the world.

The findings of this study can be used to provide prescriptive directions to policy makers of Africa's LDEs and development agencies who are in charge of improving telecommunications access in these countries. These policy-makers and development agencies can explore and analyze the strategies mentioned above as well as examples of countries that have used similar strategies to improve on their levels of telecommunications activities. This can be done considering that certain developing economies that were once LDEs, both large and small in size, have been able to establish high quality telecommunications services as well as some developed countries, despite their poor economic conditions.

\section{REFERENCES}

Alreck, P.L. and Settle, R. 1996. The Survey Research Handbook. Irwin, New York.

Brancheau, J. and Borton, R. 1999. Information Technology Adoption and Implementation: A Longitudinal Multi-method Approach. University of Colorado Press, Boulder

Cutler, T. 1994. Contemporary Telecommunications Issues in the Pacific. Pacific Telecommunications Review. 16 (2) 3-8.

Diop, O. 1997. Impact of Electronic Communications on African Development - A UN Report. http://www.bellanet.org/partners/aisi/proj/studies.htm

Green, S., Salkind, N., and Akey, T. 1997. Using SPSS for Windows. Prentice Hall, New Jersey.

Harrington, A. 1995. Companies and Capital in Asia-Pacific Telecommunications. J. Ure, Ed. Telecommunications in Asia. Hong Kong University Press, Hong Kong 81-110

Hudson, H. (2002). Universal access to the new information infrastructure. In L. A. Lievrouw, \& S. M. Livingstone (Eds.), Handbook of new media: Social shaping and consequences of ICTs (pp. 369-383). London: Sage.

ITU-International Telecommunications Union (2007). 2006 Telecommunications Indicators. ITU, Geneva. Jelinek, M. and Markham, S. (2007). Industry-University IP Relations: Integrating Perspectives and Policy Solutions. IEEE Transactions on Engineering Management. New York: May 2007.

Vol.54, Iss. 2; pg. 257 
Jensen, M. 1999. Continental Connectivity Indicators. The Association for Progressive Communications. South Africa.

Jhunjhunwala, A. (2003). Fibre access network for India as India poises for growth. IEEE Proceedings-Circuits, Devices \& Systems, Dec2003, Vol. 150 \# 6, pp. 467-472

Kaba, B., N'Da, K. and Mbarika V. (2008). Understanding the Factors Influencing the Attitude Toward and the Use of Mobile Technology in Developing Countries: A Model of Cellular Phone Use in Guinea. Proceedings of the 41st Hawaii International Conference on System Sciences (IEEE Computer Society), January 2008.

Khan, Emdad H.(1992). The Stages of Evolution of Information Syatems Functions: Findings in the Barain Environment. IEEE Transactions on Engineering Management. New York: Feb 1992. Vol 39.\#1, p. 84

Kifle, M., Mbarika., V., Okoli, C., Tsuma, C., Wilkerson, D. and Tan, J. (2008). A TeleMedicine Transfer Model for Sub-Saharan Africa. Proceedings of the 41st Hawaii International Conference on System Sciences (IEEE Computer Society), January 2008.

Kifle, M. Mbarika, V. and Joseph Tan. (2007). Telemedicine Transfer in Sub-Saharan Africa: Investigating Infrastructure and Culture. Proceedings of the International Federation on Information Processing, Working Group 9.4. Conference, Sao Paulo, Brazil, May 28-30.

Kueng, P. and Wettstein, T. 1999. Measuring Customer Satisfaction using IT: A Case Study. Sixth European Conference on Information Technology Evaluation. Uxbridge, UK.

Littlechild, S. 1978. Organization and Performance: An International Comparison of Telecommunications Systems. P. Polishuk and M. O’Bryant, eds. Telecommunications and Economic Development. Horizon House International, Boston.

Loch K., Straub, D., and Kamel, S. (2003), "Diffusing the Internet in the Arab world: The role of Social Norms and Technological Culturation," IEEE Transactions on Engineering Management, Vol. 50, February Issue 1; p. 45

Maddy, M. 2000. Dream Deferred: The Story of a High-Tech Entrepreneur in a Low-Tech World. Harvard Business Review, May-June 2000.

Mbarika, V. 2001. Africa's Least Developed Countries' Teledensity Problems and Strategies. ME \& AGWECAMS Publishers, Yaoundé, Cameroon.

Mbarika, V. (2004a). TeleEducation in Sub-Saharan Africa: A Breakout Approach to Sub-Saharan Africa's Education Dilemma. IEEE Technology and Society. Vol. 22, \#4, pp. 20-26.

Mbarika, V., Jensen, M., Meso, P. 2002a. Cyberspace Across Sub-Saharan Africa: From Technological Desert Towards Emergent Sustainable Growth? Communications of the ACM. December 2002.

Mbarika, V., Okoli, C., Byrd, T., and Datta, P. (2005). The Neglected Continent of IS Research: A Research Agenda for Sub-Saharan Africa. Journal of the Association for Information Systems (JAIS), Vol. 6, \# 5, pp.130-170.

Mbarika, V. \& Mbarika, I. (2006, May). Africa calling: burgeoning wireless networks connect Africans to the world and each other. IEEE Spectrum, 43(5), 56-60.

McCoy, S. and Mbarika, V. (2005). Teledensity Growth Strategies for Latin America: The Case of Colombia and Ecuador. Communications of the Association for Information Systems (CAIS), Vol. 16, \#2.

Meso, P., Mbarika, V., and Musa, P. (2005). An Empirical Investigation of Exploratory Factors of Consumer Uses of Mobile Information and Communications Technologies in Sub-Saharan Africa: Precursors to M-Commerce. Information Systems Journal (ISJ), Vol. 15, pp. 119-146.

Meso, P., Mbarika, V. and Sood, S. (2007a). An Overview of Potential Factors for Effective Telemedicine Transfer to Sub-Saharan Africa. IEEE Transactions on Information Technology in BioMedicine, In Press.

Meso, P., Mbarika., V., and Musa, P.,(2007b) Telecommunications Stakeholders Perceptions of Teledensity: A Comparison of Stakeholders in Latin American Region to those in Sub-Saharan Africa, Proceedings of the Fortieth Annual Hawaii International Conference on Systems Sciences, January 3-6, Kona-Waikoloa, Hawaii: p 68 
Montealegre, R. 1999. A Temporal Model of Institutional Interventions for Information Technology Adoption in Less-Developed Countries. Journal of Management Information Systems. 16 (1), 207232.

M'sene, S. (2007). The Mobile Phone revolution and the call box business in Cameroon. L'Effort Camerounais, October 26, 2007. http://www.leffortcamerounais.com/

Musa, P., Meso, P., and Mbarika, V. (2005). Toward Sustainable Adoption of Technologies for Human Development in Sub-Saharan Africa: Precursors, Diagnostics, and Prescriptions. Communications of the Association for Information Systems (CAIS), Vol. 15, \# 33.

Okoli (2003). Expert assessments of e-commerce in Sub-Saharan Africa: A theoretical model of infrastructure and culture for doing business using the Internet. Doctoral Dissertation, Louisiana State University, Baton Rouge, USA.

Okoli, C., Mbarika, V., and McCoy, S. (2005). Expert Assessments of Cultural Effects on E-Business in Developing Economies. Proceedings of the 2005 IFIP WG9.4 International Conference, Abuja, Nigeria.

Robinson, J. P., Shaver, P. R., and Wrightsman, L. S. 1991. Criteria for Scale Selection and Evaluation. J. P. Robinson, P. R. Shaver, and L. S. Wrightsman, eds. Measures of Personality and Social Psychological Attitudes. Academic Press, San Diego.

Rogers, E. M. 1995. Diffusion of Innovations, $4^{\text {th }}$ Ed. New York:The Free Press.

Sekizawa. T. 1995. Critical Formation for Building Telecomm Infrastructure in Developing Economies: Utilization of Private Funds and Mission of Suppliers. Telecom 95, 7th World Telecommunications Forum, Strategies Summit Speakers' Papers, Breaking Down Barriers Towards the Global Information Society Session 13-6. ITU, Geneva.

Soedarsono, Ardik A. Murray, Susan L, Omurtag, Yildirim (1998). Productivity Improvement at High-Tech State-Owned Industry - An Indonesian Case Study of Employee Motivation. IEEE Transactions on Engineering Management. Vol. 45. Iss. 4; p 388

Sood, S., Nwabueze, S., Mbarika, V., Prakash, N., Chatterjee, S., Ray, P., and Mishra, S. 2008). Electronic Medical Records: A Review Comparing the Challenges in Developed and Developing Countries. Proceedings of the 41st Hawaii International Conference on System Sciences (IEEE Computer Society), January 2008.

Tomlinson, C. (2002). Africa's Wireless Usage Surges. Associated Press, July 15, 2002

Travica, B. 2002. Diffusion of Electronic Commerce in Developing Economies: The Case of Costa Rica. Journal of Global Information Technology Management, 5(1), pp. 4-24.

United Nations Economic Commission for Africa --UN-ECA. 1999. The African Connection Rally-Country Fact Sheets. United Nations, New York.

United Nations Information and Communication Technologies Task Force (UNICTTask Force) (2002). Information and communication technologies (ICTS) in Africa-A status report. Retrieved September, 2007, from http://www.unicttaskforce.org/thirdmeeting/ documents/jensen\%20v6.htm

Wilson E., J. and K.Wong. 2003. African information revolution: A balance sheet. Telecommunications Policy, vol. 27, no. 1-2, pp. 155-117.

Wolcott, P., Press, L., McHenry, W., Goodman, S., and Foster, W. 2001. A Framework for Assessing the Global Diffusion of the Internet. Journal of the Association for Information Systems, 2(6).

Yin, R. K. 2002. Case Study Research, Design and Methods, 3rd ed. Newbury Park, Sage Publications 